\title{
A technological pedagogical content knowledge (TPACK) assessment of pre- service EFL teachers learning to teach English as a foreign language
} \\ Sarıçoban, A.., Tosuncuoğlu, İ \& Kırmızı, Ö. (2019). A technological pedagogical content knowledge (TPACK) assessment of pre-service \\ EFL teachers learning to teach English as a foreign language, Journal of Language and Linguistic Studies, 15(3), 1122-1138. \\ Submission Date:24/07/2019 \\ Acceptance Date:18/08/2019
}

\begin{abstract}
The aim of the present paper is to measure the technological pedagogical content knowledge (TPACK) of preservice EFL teachers learning to teach English as a foreign language (EFL). In order to collect data, a survey, designed and validated by Başer et al. (2016), was used. The survey consists of five sections which are technological knowledge (TK), content knowledge (CK), pedagogical knowledge (PK), pedagogical content knowledge (PCK) and a fifth section that combines technological content knowledge (TCK), technological pedagogical knowledge (TPK), and TPACK items. This survey intends to assess pre-service EFL teachers' competencies in pedagogies and technologies. The present study is quantitative in nature. The participants of the study are 77 pre-service EFL teachers. The results indicate that pre-service EFL teachers have a satisfactory level of competence in technological pedagogical content knowledge; yet, there are also some areas in which they need development.
\end{abstract}

(C) 2019 JLLS and the Authors - Published by JLLS.

Keywords: English as a foreign language; technology integration; technological pedagogical content knowledge; teacher education; assessment

\section{Introduction}

The introduction of the concept "technological pedagogical content knowledge" (TPACK) to educational research is a recent development. The concept was put forward by Pierson (2001), followed by other researchers who focused on the content-specific nature of technology integration (Angeli \& Valanides, 2005; Koehler \& Mishra, 2005; Margerum-Leys \& Marx, 2004; Wallace, 2004). It was adopted rapidly by researchers as a way of measuring the technology-related competence of teachers. In particular, the influential study of Mishra and Koehler (2006) highly popularized the construct of TPACK.

The concept of TPACK was predicated on Shulman's (1986) model of pedagogical content knowledge (PCK) with the integration of the construct of technological knowledge. There are three fundamental knowledge components in TPACK, namely pedagogical knowledge (PK), content

\footnotetext{
${ }^{*}$ Corresponding author. Tel.: +0-506-5339044

E-mail address: ozkankirmizi@gmail.com
} 
knowledge (CK), and technological knowledge (TK). The basic claim of the model is that the proper combination of these fundamental knowledge components give way to four other types of knowledge, which are pedagogical content knowledge (PCK), technological pedagogical knowledge (TPK), technological content knowledge (TCK), and technological pedagogical content knowledge (TPACK) (see figure 1).

In line with the developments in the fields of knowledge and technology, a change in the qualities expected from teachers up until today has also taken place (Rakes, Fields \& Cox, 2006: 420). Out of these qualities, integrating technology into classrooms appropriately comes to the forefront (Efe, 2011:230). In addition, teachers are also expected to train individuals who can efficiently use the latest technology. However, in order to realize these duties and expectations, teachers should possess the competence of using technology at a sufficient level.

When the fact that students can use technological devices such as smartphones, computers and tablets at ease is considered, teachers are expected to improve themselves in this field at least as much as their students do. Otherwise, teachers' lack of use of these technological tools, which are seen as a part of ordinary needs, may lead to disharmony among students and teachers.

\section{Literature Review}

Technology has improved tremendously since the invention of the fire or human beings' experiments with agricultural activities in the ancient times and it has transformed into an indispensable part of human beings' daily lives through inventions such as the phone, television, radio and the internet in communication, and planes, trains and automobiles in transportation (Bacanak, Karamustafaoğlu, Köse, 2003:194). Accordingly, people should follow technological developments and know how to utilize them in order to make their lives easier in accordance with the changes in societies. They should first develop a passion for technology and as a result of this passion, they should allocate it a place in their lives.

The technological revolution which maintains its effects in each field has made it mandatory to make some amendments to educational settings as a learning environment and their educational policies. In order to catch up with this change, bringing technology into institutions alone is not the only need. There is also the need to integrate technology into education settings appropriately and the learning process should be managed in an efficient and productive way.

In today's world, education and technology cannot be considered independent of each other and the integration of technology into education has become a necessity (Dumpit \& Fernandez, 2017; Liao, 2007). The integration of technology as a tool is used for enriching students' learning, better understanding of the lesson contents and developing higher order thinking skills. According to Wachira and Keengwe (2011), the integration of technology into education can be defined as the appropriate integration of the procedures of learning and teaching, including the evaluation of lessons and learning outcomes, with the technology that is suitable for the goals.

Teachers who are one of the most significant components of classroom management have important responsibilities in this process. Some of these responsibilities are: having a positive attitude towards technology, being willing to use technology in learning environments and making use of all types of visual and auditory supplementary equipment in addition to textbooks, manuals and being open to all types of support to use the equipment (Adigüzel \& Berk, 2009:66). 


\subsection{The concept of TPACK}

This concept has emerged as an efficient way of conceptualizing research and application in classrooms that are rich with regard to technology (Koehler, Mishra, Kereluik, Shin, \& Graham, 2014). Researchers frequently used the concept of Technological Pedagogical Content Knowledge (TPACK) (Mishra \& Koehler, 2006) as a way to define the knowledge required for learning in the digital age (Chai, Koh \& Tsai, 2013). Mishra and Koehler (2006, cited in Öz, 2015) organized the framework of the concept of TPACK in order to explain the dynamic relationship between content knowledge, pedagogical knowledge and technology knowledge. This framework can also be named as the emerging form that goes well beyond these three components and this framework forms the base of the teaching profession of the 21st century (figure 1.).

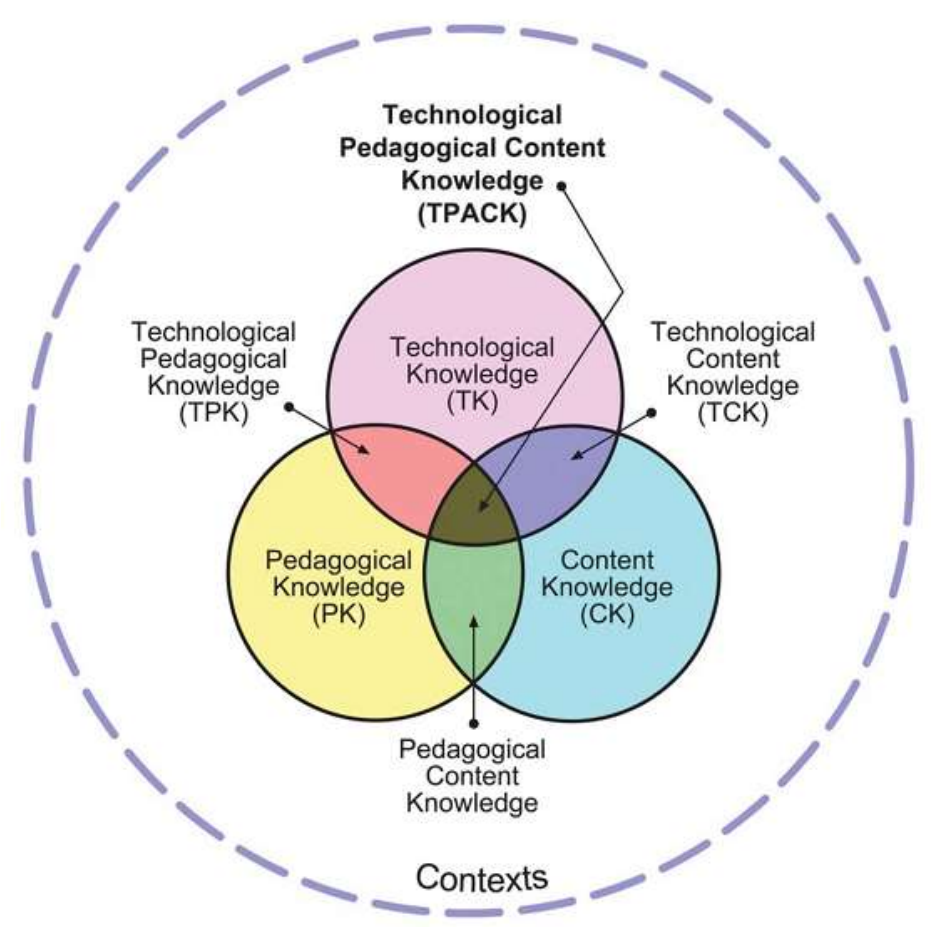

Figure 1. TPACK Model formed by Koehler \& Mishra (2009)

When the figure above is analyzed, three main components which are regarded as necessary for the active use of technology in learning and teaching contexts are underlined. These components are "Technology Knowledge", "Pedagogical Knowledge" and "Content Knowledge" (Konakman et al., 2013:63).

\subsubsection{Technology knowledge (TK)}

In addition to modern technologies such as computers, the internet and videos, technology knowledge includes widely-used overhead projectors, the blackboard and books (Mishra \& Koehler, 2005; Koehler \& Mishra, 2008: 7; Schmidth, Baran, Thompson, Mishra, Koehler, \& Shin, 2009: 125).

This knowledge expresses technological literacy and the efficient use of types of technology and technological tools in both daily life and also education contexts. In comparison to the other types of knowledge in the model, it is more fluid and open to change. Consequently, it constantly renews and updates itself. Mishra and Koehler (2006: 1024) stated that teachers should get support in this knowledge type as the dynamism of technology causes motion in each field it enters. 


\subsubsection{Pedagogical knowledge (PK)}

In general terms, pedagogy is the response to the following questions through various views: What is learning and how does it take place? How does knowledge emerge and what is significant knowledge? and How is knowledge realized? (Özmantar, Akkoç \& Bingölbali 2008:181).

The methods and techniques that are used pedagogically in TPACK are the tools for teaching contents in various ways considering the context in which students learn.

Moreover, the educational approach that is going to be used in a teaching process is also decided thanks to the pedagogical knowledge possessed (Konakman, Yanpar Yelken \& Sancar Tokmak 2013:670). The teachers that do not have in-depth knowledge of pedagogy cannot provide sufficient answers to how students internalize knowledge and how they can have a positive attitude towards learning and science.

\subsubsection{Content knowledge (CK)}

All the knowledge a teacher possesses in a certain field, in which s/he has had education and will be teaching, is called content knowledge. This knowledge has a very significant place in educators' teaching life (Koehler \& Mishra, 2009:70).

Considering the fact that the content knowledge a teacher has equals to the knowledge $\mathrm{s} / \mathrm{he}$ will teach to students, it is possible that a teacher who does not have sufficient and sound content knowledge may transfer deficient or wrong knowledge to students. In order to prevent this, teachers should be open to all types of novelties and changes in their field. They should closely follow them and be able to apply them in teaching environments.

According to Shulman (1986:10), teachers must know and follow the frameworks that accommodate and organize all types of realities, concepts, theories, rules and ideas that are related to their field.

\subsubsection{Technological pedagogical content knowledge (TPACK)}

It consists of the three main knowledge types in addition to the mutual interaction between these knowledge types.

a) Content knowledge,

b) Pedagogical and

c) Technology knowledge

It is a more different and comprehensive knowledge compared to the definitions of these components and it is at a higher level. Differentiating between the components that form TPACK is both difficult and also it leads to big losses in the process of learning and teaching.

On the other hand, there is also much criticism directed towards the structure of the TPACK framework (Koehler et al., 2014). Some researchers suggested that it is a difficult and meaningless task to try to define and describe the different knowledge types (Cox \& Graham, 2009) and that it is insufficient to differentiate between the categories in a meaningful way (Archambault \& Barnett, 2010). Graham (2011) claimed that the TPACK framework is usually implemented without clearly making out the complication it added to the original PCK framework, and Angeli and Valanides (2009) emphasized the need for a clearer definition regarding the nature of the central category of TPACK.

There is also an integrative perspective in which teachers integrate technology, pedagogical and content knowledge and form their own TPACK. In their experimental study, Cavanagh and Koehler (2013) evaluated the use of the TPACK framework and they made suggestions by which researchers can aim for more valid results. The following table summarizes that basic constructs of TPACK. 
Table 1. Summary of TPACK construct

\begin{tabular}{|c|c|}
\hline TPACK construct & explanation \\
\hline Content knowledge (CK) & Knowledge about the actual subject matter that is to be learned or taught \\
\hline Pedagogical knowledge (PK) & Deep knowledge about methods of teaching and learning \\
\hline $\begin{array}{l}\text { Pedagogical content knowledge } \\
\text { (PCK) }\end{array}$ & $\begin{array}{l}\text { The blending of content and pedagogy into an understanding of how } \\
\text { particular topics are presented for instruction }\end{array}$ \\
\hline Technology knowledge (TK) & $\begin{array}{l}\text { Knowledge of how to use technological tools such as hardware, software, } \\
\text { and the Internet }\end{array}$ \\
\hline $\begin{array}{l}\text { Technological content knowledge } \\
\text { (TCK) }\end{array}$ & $\begin{array}{l}\text { Knowledge about the manner in which technology and content are } \\
\text { mutually related }\end{array}$ \\
\hline $\begin{array}{l}\text { Technological pedagogical and } \\
\text { content knowledge (TPACK) }\end{array}$ & Knowledge required to teach effectively with technology \\
\hline
\end{tabular}

(Adapted from Redmond \& Peled, 2018)

\section{The significance of the study}

As is known, the changes and novelties in technology directly affect teaching processes. Especially, the fact that technology is related to learning-teaching processes is seen as significant for a complete learning to take place (Özgen, Narl, Alkan, 2013: 44). To be more specific, it can be said that technology has the capacity to improve student comprehension and complex thinking skills (Dreyer \& Nel, 2003; Kozma, 2003; Lei \& Zhao, 2007), develop student motivation to learn (Papastergiou, 2009), and more importantly enhance students' 21 st century skills (Kleiman, 2004).

Studies suggest that the integration of technology into education is beneficial for teachers and students in many respects. Some of these benefits are rapid knowledge transfer to students and creating individual learning environments; to achieve these goals, technology provides the interaction among all the stakeholders in the teaching process and it supports cooperative learning environments (İşman, 2002). The integration of technology is a multifaceted and slow process and it is stated that teachers have one of the most important duties in this process (Wachira \& Keengwe, 2011). Excluding teachers from this process, ignoring the pedagogical uses of technology and simply equipping teaching environments with technological devices lead to an inefficient integration of technology (Ellis, Dare, \& Roehrig, 2016).

On the other hand, many studies revealed that although teachers and pre-service teachers actively used computers and various technologies in their lives outside schools, they did not use education technologies in their classes at a sufficient level and they did not make an effort for this goal (Akkoyunlu \& Kurbanoğlu, 2003; Erdemir, Bakırcı \& Eyduran, 2009).

There are a number of studies conducted on TPACK in Turkish context. One study, conducted by Kozikoğlu and Babacan (2019), found that the level of Turkish EFL teachers is relatively high and FATIH project contributed to this high level. Their study also found that EFL teachers' TPACK evaluations do not differ in relation to experience. In another study, which focused not only on EFL teachers but also teachers from different branches, was conducted by Durdu and Dag (2017). They found that the instructional process employed within the scope of the study contributed greatly to the TPACK development of teachers. They concluded that more attention should be paid to TPACK in teacher education programs. In another study conducted in Turkish context (Özer, 2018), the researcher found that pre-service teachers use computers mostly for simple tasks such as sending e-mail and presenting presentations rather than more instructional purposes. The researcher also concludes more attention should be spared for the technology integration in teacher education programs. 
TPACK also becomes the focus of a variety of studies. In a study conducted in China by Zhang, Liu, and Cai (2019) on primary school teachers, the results indicated that the teachers engaged in more extensive group collaborations had a rich, organized and flexible knowledge structure of TPACK. In terms of age effects, that study found that younger teachers turned out to be better in terms of pedagogical knowledge and pedagogical content knowledge, while more experienced teachers scored higher in terms of technological knowledge and pedagogical knowledge.

Similar to its prevalence in all the subfields of education, the use of technology is highly significant for English teaching as well. It may be thought that the pre-service teachers that do not have education in accordance with technology during undergraduate education will have insufficient skills when they start teaching. However, the teachers who improve themselves in their field, closely follow technology and integrate it into the classroom environment can be sufficient teachers. Consequently, it may be beneficial to compensate for these deficiencies by teachers' own opportunities or by the support of governments. This study aimed to examine pre-service English teachers' perceptions of technological pedagogical content knowledge. For this purpose, the following research questions were formulated:

1. What are the pre-service and in-service EFL teachers' perceptions of TPACK?

2. Do the participants' views on the sub-dimensions of TPACK differ in terms of gender, whether or not they have taken formation, or age?

3. Do the participants' views on the sub-dimensions of TPACK differ in terms of gender, whether or not they have taken formation, their status, or age?

\section{Method}

The present study is a quantitative study based on survey method.

\subsection{Participants}

The total number of the participants is 77 . The number of female participants is $57(74,0 \%)$ and male participants is $19(24,7 \%)$. In terms of age, the number of those in 21-23 age range is $43(55,8 \%), 24-28$ age range is $20(26,0 \%)$, and 29 -over is $12(15,6 \%)$. The number of pre-service teachers in the present study is $67(87,0 \%)$ and in-service teachers is $7(9,1 \%)$. Finally, $24(31,4 \%)$ of the participants have taken teaching formation education and $13(16,9 \%)$ of them haven't taken formation courses. The remaining part are either graduates of teaching departments or still students in teaching departments.

\subsection{Data collection tool}

In the present study, the scale which was developed and validated by Baser et al. (2016) was used. The scale consists of 7 sub-dimensions which are: (a) technological knowledge (TK), (b) content knowledge (CK), (c) pedagogical knowledge (PK), (d) pedagogical content knowledge (PCK), (e) technological content knowledge (TCK), (f) technological pedagogical knowledge (TPK), (g) technological pedagogical content knowledge (TPACK). The questionnaire is a 5-point Likert type questionnaire in which the answers range from strongly disagree (1), disagree (2), neutral (3), agree (4), to strongly agree (5). The reliability analysis of the questionnaire is given in Table 1. 
Table 2. Reliability analysis

\begin{tabular}{lll}
\hline sub-dimension & number of items & Cronbach's alpha value \\
\hline 1.Technological knowledge (TK) & 9 &, 843 \\
2. Content knowledge (CK) & 5 &, 836 \\
3. Pedagogical knowledge (PK) & 6 &, 853 \\
4. Pedagogical content knowledge (PCK) & 5 &, 865 \\
5. Technological content knowledge (TCK) & 3 &, 710 \\
6. Technological pedagogical knowledge (TPK) & 7 &, 893 \\
7. Technological pedagogical content knowledge & 4 &, 800 \\
(TPACK) & &, 946 \\
total & 39 & \\
\hline
\end{tabular}

\section{Findings}

Research question 1: What are the pre-service and in-service EFL teachers' perceptions of TPACK?

Table 3. Descriptive statistics regarding technological knowledge (TK)

\begin{tabular}{|c|c|c|c|c|}
\hline \multicolumn{5}{|l|}{ items } \\
\hline $\mathrm{N}$ & Min. & $\operatorname{Max}$ & Mean & Std. \\
\hline $\begin{array}{l}\text { 1. I can use basic technological terms (e.g. operating system, wireless } \\
77 \\
\text { connection, virtual memory, etc.) appropriately. }\end{array}$ & 1,00 & 5,00 & 4,2597 & ,76782 \\
\hline $\begin{array}{l}\text { 2. I can adjust computer settings such as installing software and } \\
\text { establishing an Internet connection }\end{array}$ & 1,00 & 5,00 & 4,0649 & ,78368 \\
\hline $\begin{array}{l}\text { 3. I can use computer peripherals such as a printer, a headphone, and a } 77 \\
\text { scanner }\end{array}$ & 2,00 & 5,00 & 4,2208 & ,77159 \\
\hline $\begin{array}{l}\text { 4. I can troubleshoot common computer problems (e.g. printer } \\
\text { problems, Internet connection problems, etc.) independently. }\end{array}$ & 1,00 & 5,00 & 3,7662 & ,94446 \\
\hline $\begin{array}{l}\text { 5. I can use digital classroom equipment such as projectors and smart } 77 \\
\text { boards }\end{array}$ & 2,00 & 5,00 & 4,3247 & ,61647 \\
\hline $\begin{array}{l}\text { 6. I can use Office programs (i.e. Word, PowerPoint, etc.) with a high } \\
77 \\
\text { level of proficiency. }\end{array}$ & 1,00 & 5,00 & 4,2208 &, 85260 \\
\hline $\begin{array}{l}\text { 7. I can create multimedia (e.g. video, web pages, etc.) using text, } 77 \\
\text { pictures, sound, video, and animation. }\end{array}$ & 1,00 & 5,00 & 3,8961 & ,98120 \\
\hline $\begin{array}{l}\text { 8. I can use collaboration tools (wiki, edmodo, 3D virtual environments, } 77 \\
\text { etc.) in accordance with my objectives }\end{array}$ & 1,00 & 5,00 & 3,5714 & 1,06904 \\
\hline $\begin{array}{l}\text { 9. I can learn software that helps me complete a variety of tasks more } \\
\text { efficiently. }\end{array}$ & 1,00 & 5,00 & 4,0649 &, 83252 \\
\hline total & & & 4,04 & \\
\hline
\end{tabular}

As can be understood from Table 2, the participants seem to agree the items regarding technological knowledge (TK) $(\mathrm{M}=4,04)$. The participants reported that they can use digital classroom equipment such as projectors and smart boards (M=4,34), and can use basic technological terms (e.g. operating system, wireless connection, virtual memory, etc.) appropriately $(\mathrm{M}=4,25)$, can use computer peripherals such as a printer, a headphone, and a scanner $(4,22)$. Finally, most of the participants stated that they could use Office programs (i.e. Word, PowerPoint, etc.) with a high level of proficiency $(M=4,22)$. 
Table 4. Descriptive statistics regarding content knowledge (CK)

\begin{tabular}{lccccc}
\hline items & N & Min. & Max. & Mean & Std. \\
\hline 1.I can express my ideas and feelings by speaking in English. & 77 & 2,00 & 5,00 & 4,2078 &, 69467 \\
2. I can express my ideas and feelings by writing in English. & 77 & 2,00 & 5,00 & 4,3506 &, 68376 \\
3.I can read texts written in English with the correct pronunciation. 76 & 1,00 & 5,00 & 4,0921 &, 73353 \\
4. I can understand texts written in English. & 77 & 3,00 & 5,00 & 4,2727 &, 57666 \\
5. I can understand the speech of a native English speaker easily. & 77 & 1,00 & 5,00 & 3,7922 &, 87866 \\
Total & 77 & & & 4,14 & \\
\hline
\end{tabular}

In relation to content knowledge (CK), the participants agreed the items in this category. Most of the participants reported that they can express their ideas and feelings by writing in English $(M=4,35)$, understand texts written in English $(M=4,27)$, and can express their ideas and feelings by speaking in English $(\mathrm{M}=4,20)$.

Table 5. Descriptive statistics regarding pedagogical knowledge (PK)

\begin{tabular}{|c|c|c|c|c|}
\hline ems & Min. & Max. & Mean & Std. \\
\hline $\begin{array}{l}\text { 1. I can use teaching methods and techniques that are appropriate } \\
\text { for a learning environment. }\end{array}$ & 3,00 & 5,00 & 4,0395 & ,55235 \\
\hline $\begin{array}{l}\text { 2. I can design a learning experience that is appropriate for the level } 77 \\
\text { of students. }\end{array}$ & 1,00 & 5,00 & 4,0260 & ,70662 \\
\hline $\begin{array}{l}\text { 3. I can support students' learning in accordance with their physical, } 77 \\
\text { mental, emotional, social, and cultural differences. }\end{array}$ & 3,00 & 5,00 & 4,1039 & 68026, \\
\hline $\begin{array}{l}\text { 4. I can collaborate with school stakeholders (students, parents, } 77 \\
\text { teachers, etc.) to support students' learning. }\end{array}$ & 3,00 & 5,00 & 4,1169 & 62774, \\
\hline $\begin{array}{l}\text { 5. I can reflect the experiences that I gain from professional } \\
77 \\
\text { development programs to my teaching process. }\end{array}$ & 3,00 & 5,00 & 4,1299 & 63558, \\
\hline $\begin{array}{l}\text { 6. I can support students' out-of-class work to facilitate their self- } \\
\text { regulated learning. }\end{array}$ & 3,00 & 5,00 & 4,1039 & 66063, \\
\hline total & & & 4,08 & \\
\hline
\end{tabular}

Table 4 presents the descriptive statistics regarding pedagogical knowledge. As we can understand from Table 4, the participants "agreed" on the issues related to their self-evaluation of pedagogical knowledge. In particular, most of the participants believe that they can reflect the experiences that they gain from professional development programs $(\mathrm{M}=4,12)$, collaborate with school stakeholders (students, parents, teachers, etc.) to support students' learning $(\mathrm{M}=4,11)$. In addition, they also think that they can support students' learning in accordance with their physical, mental, emotional, social, and cultural differences $(\mathrm{M}=4,10)$ and support students' out-of-class work to facilitate their self-regulated learning $(\mathrm{M}=4,10)$.

Table 6. Descriptive statistics regarding pedagogical content knowledge (PCK)

\begin{tabular}{|c|c|c|c|c|}
\hline$\overline{\text { items }}$ & $\mathrm{N}$ & Min. & Max. & Mean Std. \\
\hline 1. I can manage a classroom learning environment. & 77 & 3,00 & 5,00 & $4,1688,57130$ \\
\hline 2. I can evaluate students' learning processes. & 77 & 3,00 & 5,00 & 4,1169,66834 \\
\hline $\begin{array}{l}\text { 3. I can use appropriate teaching methods and techniques to suppor } \\
\text { students in developing their language skills. }\end{array}$ & t 77 & 2,00 & 5,00 & 4,1169,62774 \\
\hline 4. I can prepare curricular activities that develop students' language skills & .76 & 3,00 & 5,00 & 4,0921,56986 \\
\hline $\begin{array}{l}\text { 5. I can adapt a lesson plan in accordance with students' language skil } \\
\text { levels }\end{array}$ & $11_{77}$ & 3,00 & 5,00 & 4,1299,63558 \\
\hline total & 76 & & & 4,12 \\
\hline
\end{tabular}


The next sub-dimension is concerned about pedagogical content knowledge (PCK). The participants seem to have agreed on the items related to this category. Specifically, the participants reported that they can manage a classroom learning environment $(M=4,16)$ and adapt a lesson plan in accordance with students' language skill levels $(M=4,12)$. In addition, it can be said that the participants can evaluate students' learning processes $(\mathrm{M}=4,11)$ and use appropriate teaching methods and techniques to support students in developing their language skills $(\mathrm{M}=4,11)$.

Table 7. Descriptive statistics regarding technological content knowledge (TCK)

\begin{tabular}{lcccc}
\hline items & N Min. & Max. & Mean & Std. \\
\hline $\begin{array}{l}\text { 1. I can take advantage of multimedia (e.g. video, slideshow, etc.) to express } \\
\text { my ideas about various topics in English. }\end{array}$ & 3,00 & 5,00 & $4,3377,55275$ \\
$\begin{array}{l}\text { 2. I can benefit from using technology (e.g. web conferencing and discussion } \\
\text { forums) to contribute at a distance to multilingual communities. }\end{array}$ & & & & \\
$\begin{array}{l}\text { 3. I can use collaboration tools to work collaboratively with foreign persons } \\
\text { (e.g. Second Life, wiki, etc.) }\end{array}$ & 5,00 & 4,0260 &, 72501 \\
total & 77 & 5,00 & 3,7273 &, 73693 \\
\hline
\end{tabular}

The mean score for technological content knowledge (TCK) is 4,03, which indicates that the participants agree on the items in this category. Most of the participants stated that they can take advantage of multimedia (e.g. video, slideshow, etc.) in expressing their ideas about various topics in English $(M=4,33)$ and benefit from using technology (e.g. web conferencing and discussion forums) to contribute at a distance to multilingual communities $(M=4,02)$

Table 8. Descriptive statistics regarding technological pedagogical knowledge (TPK)

\begin{tabular}{|c|c|c|c|c|}
\hline items & Min. & Max. & Mean & Std. \\
\hline $\begin{array}{l}\text { 1. I can meet students' individualized needs by using information } \\
\text { technologies. }\end{array}$ & 2,00 & 5,00 & 3,9740 & ,64836 \\
\hline $\begin{array}{l}\text { 2. I can lead students to use information technologies legally, ethically, } 77 \\
\text { safely, and with respect to copyrights. }\end{array}$ & 2,00 & 5,00 & 3,9481 & ,68626 \\
\hline $\begin{array}{l}\text { 3. I can support students as they use technology such as virtual discussion } \\
77 \\
\text { platforms to develop their higher order thinking abilities. }\end{array}$ & 2,00 & 5,00 & 4,0000 & ,62828 \\
\hline $\begin{array}{l}\text { 4. I can manage the classroom learning environment while using } 77 \\
\text { technology in the class. }\end{array}$ & 3,000 & 5,000 & 4,19 &, 566150 \\
\hline $\begin{array}{l}\text { 5. I can decide when technology would benefit my teaching of specific } \\
\text { English curricular standards. }\end{array}$ & 2,00 & 5,00 & 4,2208 & ,66141 \\
\hline $\begin{array}{l}\text { 6. I can design learning materials by using technology that supports } \\
\text { students' language learning. }\end{array}$ & 3,00 & 5,00 & 4,2727 & ,59904 \\
\hline $\begin{array}{l}\text { 7. I can use multimedia such as videos and websites to support students' } 77 \\
\text { language learning. }\end{array}$ & 3,00 & 5,00 & 4,3896 & ,56559 \\
\hline total & & & 4,14 & \\
\hline
\end{tabular}

As for technological pedagogical knowledge (TPK), the participants agree that they have sufficient proficiency in technological pedagogical knowledge. A big number of the participants stated that they can use multimedia such as videos and websites to support students' language learning $(M=4,38)$ and 6 . design learning materials by using technology that supports students' language learning $(M=4,27)$. Moreover, the participants also reported that they feel sufficient in terms of deciding when technology would benefit my teaching of specific English curricular standards $(M=4,22)$ and managing the classroom learning environment while using technology in the class $(M=4,19)$ 
Table 9. Descriptive statistics regarding technological pedagogical content knowledge (TPACK)

\begin{tabular}{llllll}
\hline items & $\mathrm{N}$ & Min. & Max. & Mean & Std. \\
\hline $\begin{array}{l}\text { 1. I can use collaboration tools (e.g. wiki, 3D virtual environments, etc.) to } \\
\text { support students' language learning. }\end{array}$ & 2,00 & 5,00 & 3,8158 &, 76089 \\
$\begin{array}{l}\text { 2. I can support students as they use technology to support their } \\
\text { development of language skills in an independent manner. }\end{array}$ & 77 & 2,00 & 5,00 & 4,0533 &, 63445 \\
$\begin{array}{l}\text { 3. I can use Web 2.0 tools (animation tools, digital story tools, etc.) to } \\
\text { develop students' language skills. }\end{array}$ & 77 & 1,00 & 5,00 & 3,7632 &, 83056 \\
$\begin{array}{l}\text { 4. I can support my professional development by using } \\
\text { technological tools and resources to continuously improve the language } \\
\text { teaching process }\end{array}$ & 77 & 2,00 & 5,00 & 4,0658 &, 69925 \\
total & 77 & & & 3,92 & \\
\hline
\end{tabular}

Finally, when it comes to self-evaluation of participants in terms of technological pedagogical content knowledge (TPACK), it can be seen that the participants seem to have almost agreed. They agree that they are supposed to support their professional development by means of technological tools and resources to continuously enhance the language teaching process $(M=4,06)$ and support students as they use technology to support their development of language skills in an independent manner $(M=4,05)$. However, as to Web 2.0 tools, the participants do not seem to have sufficient knowledge or expertise $(\mathrm{M}=3,76)$

Research question 2: Do the participants' views on the sub-dimensions of TPACK differ in terms of (a) gender, (b) whether or not they have taken formation, (c) their status, or (d) age?

(a) gender

Table 10. The results of Mann Whitney-U test

\begin{tabular}{lllllll}
\hline & & & & & Asym.Sig \\
& gender & $\mathrm{N}$ & Mean & Std. Deviation & Std. Error Mean & (2-tailed) \\
\hline TK & female & 57 & 3,9805 &, 53622 &, 07102 & $0.015^{*}$ \\
& male & 19 & 4,3275 &, 44363 &, 10178 & \\
CK & female & 57 & 4,0737 &, 55887 &, 07402 & 0.102 \\
& male & 19 & 4,3263 &, 53421 &, 12256 & \\
PK & female & 57 & 4,0760 &, 48496 &, 06423 & 0.757 \\
& male & 19 & 4,1053 &, 52473 &, 12038 & \\
PCK & female & 57 & 4,1193 &, 46730 &, 06190 & 0.932 \\
& male & 19 & 4,1474 &, 58819 &, 13494 & \\
TCK & female & 57 & 4,0234 &, 54138 &, 07171 & 0.731 \\
& male & 19 & 4,0526 &, 55847 &, 12812 & \\
TPK & female & 57 & 4,1328 &, 48208 &, 06385 & 0,450 \\
& male & 19 & 4,1805 &, 51252 &, 11758 & \\
TPACK & female & 57 & 3,9123 &, 60225 &, 07977 & 0.976 \\
& male & 19 & 3,8947 &, 54846 &, 12582 & \\
\hline
\end{tabular}

*: significant at $\alpha=0.05$

Within the scope of the study, the researchers examined whether the participants differ in their selfevaluation based on gender. Mann-Whitney-U test was utilized in order to compare the results of male and female participants. The rest results indicate that there is statistically significant difference in terms of TK sub-dimension $(\mathrm{p}=0.015<\alpha=0.05$ ). Male participants agreed more on the items compared to 
female participants. In general, males tend to have more self-confidence in relation to technology use. As for the other sub-dimensions, no statistically significant difference was observed ( $p>\alpha=0.05$ ).

(b) status (in-service or pre-service)

Table 11. Mann-Whitney-U test results as to the status of the participants

\begin{tabular}{lllllll}
\hline & & & & & Asym.Sig \\
& status & $\mathrm{N}$ & Mean & Std. Deviation & Std. Error Mean & (2-tailed) \\
\hline TK & pre-service & 67 & 4,0431 &, 53600 &, 06548 & 0,718 \\
& in-service & 7 & 4,0794 &, 44312 &, 16748 & \\
CK & pre-service & 67 & 4,0806 &, 55165 &, 06739 & $0.030 *$ \\
& in-service & 7 & 4,6000 &, 50332 &, 19024 & \\
PK & pre-service & 67 & 4,0597 &, 50059 &, 06116 & 0,195 \\
& in-service & 7 & 4,3095 &, 44544 &, 16836 & \\
PCK & pre-service & 67 & 4,0716 &, 47572 &, 05812 & $0,015^{*}$ \\
& in-service & 7 & 4,5429 &, 47208 &, 17843 & \\
TCK & pre-service & 67 & 4,0199 &, 55620 &, 06795 & 0,870 \\
& in-service & 7 & 4,0000 &, 33333 &, 12599 & \\
TPK & pre-service & 67 & 4,1279 &, 47844 &, 05845 & 0,412 \\
& in-service & 7 & 4,2449 &, 63199 &, 23887 & \\
TPACK & pre-service & 67 & 3,8955 &, 60326 &, 07370 & 0,925 \\
& in-service & 7 & 3,9286 &, 47246 &, 17857 & \\
\hline
\end{tabular}

In order to compare the results based on the status of the participants, Mann-Whitney-U test was utilized. Based on the results, moderately significant difference in CK and PCK between in-service and pre-service teachers $(\mathrm{p}<\alpha=0.05)$. As for these sub-dimensions, in-service teachers agree with the items more than pre-service teachers. This may be attributed to experience. No statistically significant difference was observed for the other five sub-dimensions $(p>\alpha=0.05)$.

(c) whether or not they have taken formation

Table 12. Mann-Whitney-U test results as to whether or not the participants have taken formation

\begin{tabular}{lllllll}
\hline & teaching & & & & & Asym.Sig \\
& certificate & $\mathrm{N}$ & Mean & Std. Deviation & Std. Error Mean & (2-tailed) \\
\hline TK & yes & 24 & 4,0926 &, 45242 &, 09235 & 1,000 \\
& no & 13 & 4,1282 &, 60152 &, 16683 & \\
CK & yes & 24 & 4,1083 &, 42520 &, 08679 & 0,759 \\
& no & 13 & 4,0000 &, 71181 &, 19742 & \\
PK & yes & 24 & 4,0486 &, 50476 &, 10303 & 0,910 \\
& no & 13 & 3,9103 &, 52974 &, 14692 & \\
PCK & yes & 24 & 4,1167 &, 51047 &, 10420 & 0,744 \\
& no & 13 & 4,0000 &, 57735 &, 16013 & \\
TCK & yes & 24 & 4,0833 &, 59992 &, 12246 & 0,667 \\
& no & 13 & 4,1282 &, 58592 &, 16251 & \\
TPK & yes & 24 & 4,1607 &, 52161 &, 10647 & 0,771 \\
& no & 13 & 4,1429 &, 52812 &, 14647 & \\
TPACK & yes & 24 & 3,8958 &, 53118 &, 10843 & 0,281 \\
& no & 13 & 4,0192 &, 57247 &, 15878 & \\
\hline
\end{tabular}


Table 11 presents the results as to whether participants self-perceptions change based on whether they have taken teacher certificate courses or nor. The results indicate that there are no statistically significant differences in the participants self-evaluation in terms of the sub-dimensions of TPACK ( $p$ > $\alpha=0.05)$.

(d) age

Table 13. Kruskal Wallis test results for age

\begin{tabular}{|c|c|c|c|c|c|c|}
\hline & & $\mathrm{N}$ & Mean & Std. Deviation & Std. Error & $\begin{array}{l}\text { Asym.Sig } \\
\text { (2-tailed) }\end{array}$ \\
\hline \multirow[t]{4}{*}{$\overline{\mathrm{TK}}$} & $21-23$ & 43 & 4,0258 & ,52946 & ,08074 & 0,469 \\
\hline & $24-28$ & 20 & 4,1556 & ,62688 & , 14018 & \\
\hline & 29 -over & 12 & 4,1389 & ,31826 & ,09187 & \\
\hline & Total & 75 & 4,0785 & ,52808 & ,06098 & \\
\hline \multirow[t]{4}{*}{$\mathrm{CK}$} & $21-23$ & 43 & 4,0605 &, 52651 & ,08029 & $0,011^{*}$ \\
\hline & $24-28$ & 20 & 4,0600 & 62945 & , 14075 & \\
\hline & 29-over & 12 & 4,5667 & ,38925 & ,11237 & \\
\hline & Total & 75 & 4,1413 &, 56259 & 06496 & \\
\hline \multirow[t]{4}{*}{ PK } & $21-23$ & 43 & 4,0426 & ,47850 & ,07297 & 0,198 \\
\hline & $24-28$ & 20 & 4,0417 & ,56163 & , 12558 & \\
\hline & 29-over & 12 & 4,3056 & ,40722 &, 11755 & \\
\hline & Total & 75 & 4,0844 & ,49500 & 05716 & \\
\hline \multirow[t]{4}{*}{ PCK } & $21-23$ & 43 & 4,0233 & ,46845 & ,07144 & $0,015^{*}$ \\
\hline & $24-28$ & 20 & 4,1300 & ,49108 & , 10981 & \\
\hline & 29-over & 12 & 4,5000 & 47863 & , 13817 & \\
\hline & Total & 75 & 4,1280 & ,49934 & 05766 & \\
\hline \multirow[t]{4}{*}{ TCK } & $21-23$ & 43 & 4,0000 & ,57275 & ,08734 & 0,598 \\
\hline & $24-28$ & 20 & 4,0333 & ,53966 & , 12067 & \\
\hline & 29-over & 12 & 4,1667 & ,46057 & 13295 & \\
\hline & Total & 75 & 4,0356 &, 54407 & ,06282 & \\
\hline \multirow[t]{4}{*}{ TPK } & $21-23$ & 43 & 4,0897 & ,49391 & ,07532 & 0,348 \\
\hline & $24-28$ & 20 & 4,1571 & ,49029 & ,10963 & \\
\hline & 29-over & 12 & 4,3333 &, 46524 &, 13430 & \\
\hline & Total & 75 & 4,1467 & 48982 & ,05656 & \\
\hline \multirow[t]{4}{*}{ TPACK } & $21-23$ & 43 & 3,8721 & 63474 & 09680, & 0,693 \\
\hline & $24-28$ & 20 & 3,9125 & ,48852 & 10924 & \\
\hline & 29 -over & 12 & 4,0833 & ,55732 & ,16088 & \\
\hline & Total & 75 & 3,9167 & ,58462 & 06751 & \\
\hline
\end{tabular}

Finally, Kruskal Wallis test was run in order to see whether the self-evaluations of the participants differ in terms of age. The results indicate that there are statistically significant differences in CK and PCK $(p<\alpha=0.05)$. The "29-over" age group seems to rate themselves higher compared to "21-23" and "24-28" age group. This indicates that as language teachers get older they become more knowledgeable in terms of CK and PCK.

\section{Discussion and conclusion}

The present study was intended to measure the TPACK level of pre-service EFL teachers. TPACK, as is handled in the present study, consists of a number of sub-dimensions which are: (a) technological 
knowledge (TK), (b) content knowledge (CK), (c) pedagogical knowledge (PK), (d) pedagogical content knowledge (PCK), (e) technological content knowledge (TCK), (f) technological pedagogical knowledge (TPK), (g) technological pedagogical content knowledge (TPACK).

Based on the self-evaluation of the participants, it was seen that they view themselves sufficient in terms almost all sub-dimensions of TPACK. In terms of technological knowledge (TK), they were found to be particularly efficient in using digital classroom equipment such as projectors and smart boards in addition to being able to use office programs and other technological gadgets. In relation to content knowledge (CK), it was found that they can express their feelings in written English and understand texts. As for pedagogical knowledge, they reported that they can reflect on the experiences that they gained from their practicum process, they can collaborate with their friends, and can support students' learning in accordance with their physical, mental, emotional, social, and cultural differences.

As for pedagogical content knowledge (PCK), the study found that the participants feel themselves competent in terms of managing a classroom environment, adapting a lesson plan in accordance with students' skills, and evaluate students' learning process. When it comes to technological content knowledge (TCK), it was observed that the participants are good at using multimedia (e.g. video, slideshow, etc.) in expressing their ideas about various topics in English and benefit from using technology (e.g. web conferencing and discussion forums) to contribute at a distance to multilingual communities. Finally, regarding self-evaluation, the participants reported that they can support their professional development by using technological tools and resources to continuously improve the language teaching process and support students as they use technology to support their development of language skills in an independent manner. However, as to Web 2.0 tools, the participants do not seem to have sufficient knowledge or expertise.

Another focus of the study was to compare and contrast male and female participants in terms of the sub-dimensions of TPACK. The results of the tests indicated that male participants seem to be better in technological knowledge. Finally, age was another important factor that determine the participants' views on TPACK. Most of the time, in technology-related studies age negatively correlates with technology-related knowledge domains (Cheng \& Xie, 2018; Koh et al., 2014). However, the results of the present study showed that the older the participants are the more likely to agree with statements.

In general, the present study indicates that teachers have from moderate to high levels of TPACK. It is accepted literature that teacher knowledge affects teachers' actions in the classroom in addition to affecting student learning. As such, a sound TPACK implies that teachers can utilize technology in the classroom and enhance student learning. However, in cases where teachers have relatively low level of TPACK, it may be difficult to mobilize their knowledge and move them beyond their knowledge, as indicated in literature (McDougall, 2008). Hence, extensive in-service training is needed to mobilize the means of teachers in terms of TPACK.

A number of suggestions can be drawn from the present study. In the first place, the present study did not include year of experiment as a variable on the premise that the participants of the present study were all pre-service teachers and therefore do not have any experience. Another important dimension of TPACK can be the correlations between personality characteristics and TPACK, which is indicated in the literature (Inan \& Lowther, 2010; Cheng \& Xie, 2018; Koh, Chai, \& Tay, 2014; Scherer et al., 2018). Future studies can be designed to investigate personality types and TPACK. Another important dimension can be school type. From the literature, it can be understood that primary school teachers seem to have lower levels of TPACK (Koh, Chai, \& Tsai, 2014). The reasons behind this can be examined. Finally, teachers' academic background can also be taken into consideration in relation to TPACK (Cheng \& Xie, 2018; Erdogan \& Sahin, 2010). 


\section{References}

Adigüzel, O. C. \& Berk, Ş. (2009). The Methods of Reaching Information of the Teacher of Vocational and Technical Secondary Education. Electronic Journal of Social Sciences, 8(29), 64-75.

Angeli, C., \& Valanides, N. (2005). Preservice elementary teachers as information and communication technology designers: an instructional systems design model based on an expanded view of pedagogical content knowledge. Journal of Computer Assisted Learning, 21(4), 292-302

Archambault, L.M. \& Barnett, J.H. (2010). Revisiting technological pedagogical content knowledge: Exploring the TPACK framework, Computers \& Education, 55, 1656-1662.

Bacanak, A., Karamustafaoğlu, O., Köse, S. (2003). Eğitimde Yeni Bir Bakış: Eğitimde Teknoloji Okuryazarlığı. Pamukkale Üniversitesi Eğitim Fakültesi Dergisi, 14, 191-196.

Baser, D. Kopcha, T.J. \& Ozden, M.Y. (2016) Developing a technological pedagogical content knowledge (TPACK) assessment for preservice teachers learning to teach English as a foreign language, Computer Assisted Language Learning, 29:4, 749-764, DOI: 10.1080/09588221.2015.1047456

Brutt-Griffler, J. (2002). World English: A study of its development. Clevedon: Multilingual Matters.

Chai, C. S., Koh, J. H. L., \& Tsai, C.-C. (2013). A review of technological pedagogical content knowledge. Educational Technology \& Society, 16(2), 31-51.

Cheng, S.-L., \& Xie, K. (2018). The relations among teacher value beliefs, personal characteristics, and TPACK in intervention and non-intervention settings. Teaching and Teacher Education, 74, 98113. https://doi.org/10.1016/j.tate.2018.04.014

Dreyer, C., \& Nel, C. (2003). Teaching reading strategies and reading comprehension within a technology-enhanced learning environment. System, 31(3), 349-365. https://doi.org/10.1016/S0346e251X(03)00047-2

Dumpit, D. Z., \& Fernandez, C. J. (2017). Analysis of the use of social media in Higher Education Institutions (HEIs) using the Technology Acceptance Model. International Journal of Educational Technology in Higher Education, 14(1), 5.

Durdu, L., \& Dag, F. (2017). Pre-Service Teachers' TPACK Development and Conceptions through a TPACK-Based Course. Australian Journal of Teacher Education, 42(11)

Efe, R. (2011). Science Student Teachers and Educational Technology: Experience, Intentions, and Value. Educational Technology \& Society, 14 (1), 228-240.

Erdogan, A., \& Sahin, I. (2010). Relationship between math teacher candidates' technological pedagogical and content knowledge (TPACK) and achievement levels. Procedia-Social and Behavioral Sciences, 2(2), 2707-2711. https://doi.org/10.1016/j.sbspro.2010.03.400

Inan, F. A., \& Lowther, D. L. (2010). Factors affecting technology integration in K-12 classrooms: A path model. Educational Technology Research \& Development, 58(2), 137e154. https://doi.org/10.1007/s11423-009-9132-y.

Kleiman, G. M. (2004). Myths and realities about technology in K-12 schools: Five years later. Contemporary Issues in Technology and Teacher Education, 4, 248-253

Koehler, M. J. \& Mishra, P. (2008). Introducing TPCK. AACTE Committee on Innovation and Technology. (Ed.) Handbook of Technological Pedagogical Content Knowledge (TPCK) for Educators, (pp. 3-29). Mahwah, NJ: Lawrence Erlbaum Associates. 
Koehler, M.J., \& Mishra, P. (2009). What is technological pedagogical content knowledge? Contemporary Issues in Technology and Teacher Education, (CITE), 9(1), 60-70.

Koehler, M., Mishra, P., Kereluik, K., Shin, T. S., \& Graham, C. R. (2014). The technological pedagogical content knowledge framework. In Handbook of research on educational communications and technology (pp. 101-111), New York: Springer.

Koh, J. H. L., Chai, C. S., \& Tay, L. Y. (2014). TPACK-in-action: Unpacking the contextual influences of teachers' construction of technological pedagogical content knowledge (TPACK). Computers \& Education, 78, 20-29. https://doi.org/10.1016/j.compedu.2014.04.022

Koh, J. H. L., Chai, C. S., \& Tsai, C. C. (2014). Demographic factors, TPACK constructs, and teachers' perceptions of constructivist-oriented TPACK. Journal of Educational Technology \& Society, 17(1), 185-196.

Konakman, G., Yanpar Yelken, T. and Tokmak Sancar, H. (2013). Sınıf öğretmeni adaylarının TPAB "erine ilişkin algılarının çeşitli değişkenlere göre incelenmesi: Mersin Üniversitesi örneği. Kastamonu Ĕ̌itim Dergisi. 21(2), 665-684.

Kozikoğlu, İ., \& Babacan, N. (2019). The investigation of the relationship between Turkish EFL teachers' technological pedagogical content knowledge skills and attitudes towards technology. Journal of Language and Linguistic Studies, 15(1), 20-33. Doi: 10.17263/jlls.547594

Kozma, R. B. (2003). Technology and classroom practices: An international study. Journal of Research on Technology in Education, 36(1), 1e14. https://doi.org/ 10.1080/15391523.2003.10782399

Krashen, S. (2006). Free reading. School Library Journal, (9), 43-46.

Lei, J., \& Zhao, Y. (2007). Technology uses and student achievement: A longitudinal study. Computers \& Education, 49(2), 284-296.

Lewis, M. P. (2009). Ethnologue: Languages of the world. Dallas, Texas: SIL International.

Liao. Y. C. (2007). Effects of computer-assisted instruction on students' achievement in Taiwan: A meta-analysis. Computers \& Education, 48(2). 216-233.

McDougall, A. (2008). Models and practices in teacher education programs for teaching with and about ICT. In J. Voogt \& G. Knezek (Eds.), International handbook of information technology in primary and secondary education (pp. 461 - 474). NewYork: Springer

Margerum-Leys, J., \& Marx, R. W. (2004). The nature and sharing of teacher knowledge of technology in a student teacher/mentor teacher pair. Journal of Teacher Education, 55(5), 421-437. doi: $10.1177 / 0022487104269858$

McArthur, T. (2003). The Oxford guide to world English. Oxford: Oxford University Press.

Mishra, P., \& Koehler, M. (2005). Educational Technology Dy Design: Results from a Survey Assessing İts Effectiveness. In C. Crawford, C. Roger, I. Gibson, K. McFerrin, J. Price, R. Weber and D. A. Willis (Eds.), Proceedings of the Society for Information Technology \& Teacher Education International Conference (pp. 1-7). Chesapeake, VA: AACE.

Mishra, P., \& Koehler, M. J. (2006). Technological pedagogical content knowledge:A framework for teacher knowledge. Teachers College Record, 108(6), 1017-1054.

Öz, H. (2015). Assessing Pre-service English as a Foreign Language Teachers' Technological Pedagogical Content Knowledge. International Education Studies; Vol. 8, No. 5 
Ozer, Z. (2018). An investigation of prospective ELT teachers' attitudes towards using computer technologies in foreign language teaching. Journal of Language and Linguistic Studies, 14(1), 328341

Özmantar, M. F., Akkoç, H., Bingölbali, E., Demir, S. and Ergene, B. (2010). Preservice Mathematics Teachers' Use of Multiple Representations in Technology-rich Environments. Eurasia Journal of Mathematics, Science \&Technology Education, 6(1), 19-36.

Papastergiou, M. (2009). Digital game-based learning in high school computer science education: Impact on educational effectiveness and student motivation. Computers \& Education, 52(1), 1e12. https://doi.org/10.1016/ j.compedu.2008.06.004.

Pierson, M. E. (2001). Technology integration practice as a function of pedagogical expertise. Journal of Research on Computing in Education, 33(4), 413-430.

Rakes, G.C., Fields, V.S. \& Cox, K.E. (2006). The Influence of Teachers' Technology use on Instructional Practices. Journal of Research on Technology in Education, 38(4), 411-426.

Redmond, P. \& Peled, Y. (2018). Exploring TPACK among pre-service teachers in Australia and Israel, British Journal of Educational Technology, 50(4), 1-15.

Rubdy, R. and Saraceni, M. (2006). English in the world: global rules, global roles. London: Continuum.

Scherer, R., Tondeur, J., Siddiq, F., \& Baran, E. (2018). The importance of attitudes toward technology for pre-service teachers' technological, pedagogical, and content knowledge: Comparing structural equation modeling approaches. Computers in Human Behavior, 80, 67-80. https://doi.org/10.1016/j. chb.2017.11.003

Schmidt, D. A., Baran, E., Thompson, A. D., Mishra, P., Koehler, M. J., \& Shin, T. S. (2009). Technological Pedagogical Content Knowledge (TPACK): The Development and Validation of an Assessment Instrument For Preservice Teachers, JRTE, 42(2), 123-149.

Shulman, L. S. (1986). Those who understand: Knowledge growth in teaching (pp. 4-14). Educational Researcher. http://dx.doi.org/10.3102/0013189X015002004

Wachira, P., \& Keengwe, J. (2011). Technology integration barriers: Urban school mathematics teachers' perspectives. Journal of Science Education and Technology, 20(1), 17-25.

Wallace, R. M. (2004). A framework for understanding teaching with the internet. American Educational Research Journal, 41(2), 447-488. doi:10.3102/00028312041002447.

Zhang, S. Liu, Q. \& Cai, Z. (2019). Exploring primary school teachers' technological pedagogical content knowledge (TPACK) in online collaborative discourse: An epistemic network analysis, British Journal of Educational Technology, 50(5), 1-19 doi:10.1111/bjet.12751 


\section{İngilizce’yi yabancı dil olarak öğretecek öğretmen adaylarının teknopedagojik eğitim bilgilerinin bir değerlendirilmesi}

\section{$\ddot{O} \mathbf{z}$}

Bu çalışmanın amacı, İngilizce öğretimi üzerine eğitim alan İngiliz Dili Eğitimi (IDDE) öğretmen adaylarının teknopedagojik eğitim bilgilerini ölçmektir. Veri toplamak amacıyla Başer et al. (2016) tarfindan tasarlanan ve güvenirliği kanıtlanan bir sormaca kullanılmıştır. Sormaca, beş bölümden oluşmaktadır: teknolojik yeterlik, içerik bilgisi, pedagojik yeterlik, pedagojik içerik bilgisi, ve bunları bir araya getiren teknolojik içerik bilgisi, teknolojik pedagojik yeterlik ve teknopedagojik eğitim bilgisi maddeleri. Sormaca, IDE öğrencilerinin pedagojik ve teknolojik olarak yeterliklerini ölmeyi hedeflemektedir. Çalışma nicel bir çalışmadır. Çalışmanın katılımcıları, 77 İngilizce öğretmen adayıdır. Sonuçlar, İngilizce öğretmeni adaylarının yeterli derecede teknolojik ve pedagojik yeterliğe sahip olduğunu göstermektedir; ancak, gelişmeye ihtiyacı olan alanlar da vardır.

Anahtar sözcükler: İngilizce'nin yabancı dil olarak öğretimi; teknoloji entegrasyonu; teknopedagojik eğitim bilgileri; öğretmen yetiştirme; değerlendirme

\section{AUTHOR BIODATA}

Dr. Arif SARIÇOBAN has worked as an associate professor of ELT at Hacettepe University for 20 years and currently works at the Department of ELL at Selçuk University as a full professor. Dr. Sarıçoban the editor-inchief for an international journal.

Dr. İrfan Tosuncuoğlu received his Bachelor's Degree from Selcuk University, English Language Teaching Department and received his Ph.D. abroad. He works as an Assistant Professor at Karabuk University, English Language and Literature Department. His research areas are linguistics and ELT.

Dr. Özkan Kırmızı works as an associate professor at English Language and Literature Department at Karabuk University. He completed his Ph.D at Hacettepe University, English Language and Teaching Department. His interest areas are L2 teacher education and pedagogical content knowledge. 